\title{
THIRD STATUS REPORT: TESTING OF AGED SOFTWOOD FIBERBOARD MATERIAL FOR THE 9975 SHIPPING PACKAGE
}

\author{
W. L. Daugherty \\ Savannah River National Laboratory \\ Materials Science \& Technology
}

Publication Date: December 2011

Savannah River Nuclear Solutions

Savannah River Site

Aiken, SC 29808

This document was prepared in conjunction with work accomplished under

Contract No. DE-AC09-08SR22470 with the U.S. Department of Energy. 


\section{DISCLAIMER}

This work was prepared under an agreement with and funded by the U.S. Government. Neither the U. S. Government or its employees, nor any of its contractors, subcontractors or their employees, makes any express or implied: 1 . warranty or assumes any legal liability for the accuracy, completeness, or for the use or results of such use of any information, product, or process disclosed; or 2. representation that such use or results of such use would not infringe privately owned rights; or 3. endorsement or recommendation of any specifically identified commercial product, process, or service. Any views and opinions of authors expressed in this work do not necessarily state or reflect those of the United States Government, or its contractors, or subcontractors. 
Third Status Report: Testing of Aged Softwood Fiberboard Material for the 9975 Shipping Package

\section{APPROVALS:}

W. L. Daugherty

Date

Author, Materials Science and Technology

T. E. Skidmore

Date

Technical Review, Materials Science and Technology

K. A. Dunn

Date

Pu Surveillance Program Lead, Materials Science and Technology

G. T. Chandler

Manager, Materials App \& Process Tech

Date

E. R. Hackney

Date

NMM Engineering

\section{REVIEWS:}

D. R. Leduc

Date

Savannah River Packaging Technology 


\section{Revision Log}

$\begin{array}{lll}\text { Document No. } & \text { SRNL-TR-2011-00327 Rev. No. } 0\end{array}$

Document Title Third Status Report: Testing of Aged Softwood Fiberboard Material for the 9975 Shipping Package

Rev. \# Page \# Description of Revision Date

$\begin{array}{llr}0 \text { all } \quad \text { Original document } & \text { 12/13/11 }\end{array}$ 


\section{$\underline{\text { Summary }}$}

Samples have been prepared from a 9975 lower fiberboard subassembly fabricated from softwood fiberboard. Physical, mechanical and thermal properties have been measured following varying periods of conditioning in each of several environments. These tests have been conducted in the same manner as previous testing on cane fiberboard samples.

Overall, similar aging trends are observed for softwood and cane fiberboard samples, with a few differences. There is no clear trend thus far to indicate one material ages in a manner significantly different from the other material. Some softwood fiberboard properties degrade faster in some environments, while cane fiberboard degrades faster with regards to other properties and environments. Given the limited aging time accumulated to date in the elevated humidity environments, it is recommended that aging and testing of softwood fiberboard continue for another year.

Post-conditioning data have been measured on samples from a single softwood fiberboard assembly, and baseline data are also available from a limited number of vendor-provided samples. This provides minimal information on the possible sample-to-sample variation exhibited by softwood fiberboard. Data to date are generally consistent with the range seen in cane fiberboard, but some portions of the data trends are skewed toward the lower end of that range. Further understanding of the variability of softwood fiberboard properties will require testing of additional material.

\section{Background}

Cane fiberboard wall sheathing is specified for thermal insulation and impact resistance in 9975 shipping packages. Softwood fiberboard manufactured by Knight-Celotex was approved as an acceptable substitute for transportation in 2008. Data in the literature [1] show a consistent trend in thermal properties of fiberboard as a function of temperature, density and/or moisture content regardless of material source. Thermal and mechanical properties were measured for un-aged softwood fiberboard samples, and found to be sufficiently similar to those of un-aged cane fiberboard to support the acceptance of 9975 packages with softwood fiberboard overpack into KAMS for storage. The continued acceptability of aged softwood fiberboard to meet KAMS storage requirements was the subject of subsequent activities.

This is an interim status report for experiments carried out per Task Technical Plan WSRC-TR2008-00024 [2], which is part of the comprehensive 9975 package surveillance program [3]. The primary goal of this task is to validate the preliminary assessment that Knight-Celotex softwood fiberboard is an acceptable substitute for cane fiberboard in the 9975 shipping package overpack, and to verify whether the long-term performance of these two materials in a storage environment is comparable.

\section{Experimental Method}

A lower fiberboard subassembly fabricated from softwood fiberboard for use in a 9975 shipping package was obtained from KAMS. Samples were removed from this subassembly for 
conditioning and testing to track the potential degradation in physical, thermal and mechanical properties. Samples were initially aged in 4 environments.

- 250F oven (nominal humidity of $\sim 1 \% \mathrm{RH}$ )

- 215F oven (nominal humidity of $\sim 1 \% \mathrm{RH}$ )

- 185F oven (nominal humidity of $\sim 2 \% \mathrm{RH}$ )

- 185F, 30\%RH environmental chamber

Additional samples began aging in 2 additional environments in 2011.

- 160F, 50\%RH environmental chamber

- 125F, 70\%RH environmental chamber

The sample configurations and test methodologies are the same as used for aging and testing cane fiberboard samples $[4,5]$. Samples for physical property measurements are approximately 2 inch cubes, and receive periodic measurement of weight and dimensions. Two of these samples are conditioning in each of the 6 environments. Samples for compression testing are also approximately 2 inch cubes. These samples were placed in 5 of the environments (all environments except $215 \mathrm{~F}$ oven). A few of these samples are removed periodically for testing. Since the compression test is destructive, these samples are not returned to the conditioning environment. Several additional compression samples were added to each of the original environments in December 2009 to provide replicate data points and longer exposures. A few compression samples currently remain in their conditioning environment.

Testing for thermal properties includes both thermal conductivity and specific heat capacity. Thermal conductivity samples are approximately $7 \times 7 \times 1.3$ inches. Two of these samples are conditioned in each of 5 environments (all except 185F oven) and tested periodically. In each sample pair, one is oriented for axial heat flow, and the other is oriented for radial heat flow (relative to the package geometry). Thermal conductivity is measured at 2 mean temperatures -25 and 50C (77 and 122F) - for all samples, and is also measured at 85C (185F) for 185F and hotter aging environments.

Specific heat capacity samples are cylindrical, approximately 1 inch diameter and 1.5 inches high. Three of these samples are conditioned in each of 2 environments (250F oven and 185F 30\%RH chamber) and tested periodically. Specific heat capacity is measured for each of two mean temperatures - 25 and 52C (77 and 125F). Of these two temperatures, 125F provides the more reliable results, with less scatter among multiple trials.

Conditioning of samples began in November 2008. Thermal and physical property samples were characterized before conditioning, and separate compression samples were tested without conditioning to document baseline behavior. The three oven environments have been maintained on an almost continuous basis, while the environmental chambers have experienced varying degrees of down-time. Therefore, the samples in the 185F 30\%RH environment have not accumulated as much total exposure time as the oven samples. The samples in the other humid environments, which began conditioning in early 2011, have accumulated even less time at temperature. 


\section{$\underline{\text { Results }}$}

The physical property samples are measured on an approximately weekly basis. These data (for one of each pair of samples) are shown in Figure 1 on a normalized basis (each datum is divided by its corresponding value after the first conditioning period). This normalization allows for a direct comparison of degradation between samples with different starting values. The rates of change in the weight, density and dimensions of these samples are summarized in Table 1 for all samples. Comparable rates for cane fiberboard samples over the same aging period are also shown in Table 1, for comparison.

Compression testing is performed with the load applied either parallel or perpendicular to the fiberboard layers. Typical stress-strain curves for softwood fiberboard samples tested in the parallel orientation are shown in Figure 2. Typical stress-strain curves for softwood fiberboard samples tested in the perpendicular orientation are shown in Figure 3.

Because of variation in the shape of the stress-strain curve from one sample to another, two metrics have been used to provide a comparison of compression test performance. For samples of both orientations, the area under the stress-strain curve up to a strain of $40 \%$ provides a metric that is roughly proportional to the energy absorbed by the material. In addition, samples tested in the parallel orientation experience an initial stress peak as the layers start to buckle. This buckling strength provides a second metric for comparison of the parallel orientation samples. These metrics are summarized in Figure 4, along with comparable data for cane fiberboard samples, for samples tested in the parallel orientation. The area under the stress-strain curve to a strain of $40 \%$ data are summarized in Figure 5, along with comparable data for cane fiberboard samples, for samples tested in the perpendicular orientation.

Thermal conductivity data for each sample are presented in Figure 6. Similar trends are seen for each of the three test temperatures - 25, 50 and 85C. Since the baseline thermal conductivity varies for each sample, normalized data are shown in Figure 7, and show the relative change from the first data point (after $\sim 8$ weeks conditioning). Comparable normalized data for typical cane fiberboard samples are also shown in Figure 7. A more complete comparison of thermal conductivity degradation rates for softwood and cane fiberboard samples is shown in Table 2.

Specific heat capacity results are summarized in Figure 8. Due to the degree of scatter in individual results, data from each trial for all 3 samples in a given environment are averaged for each conditioning period. Comparable data for cane fiberboard samples are also shown in Figure 8.

\section{$\underline{\text { Discussion }}$}

Overall, similar aging trends are observed to date for softwood and cane fiberboard samples. In some cases, the softwood fiberboard properties degrade faster than those of cane fiberboard, and in other cases, the cane fiberboard properties degrade faster. However, most properties in most of the aging environments degrade at essentially the same rate for both softwood and cane fiberboard. 
The previous softwood fiberboard status report [6] observed that softwood fiberboard degraded faster than cane fiberboard with regard to several properties when aged in the $185 \mathrm{~F} 30 \% \mathrm{RH}$ environment. At that time, this was the only elevated humidity environment being used to age softwood fiberboard samples. In order to address whether softwood fiberboard would degrade faster than cane fiberboard in other elevated humidity environments, physical property, compression and thermal conductivity samples began conditioning in two additional elevated humidity environments - 125F 70\%RH and 160F 50\%RH. Data are currently available for aging times of up to 32-38 weeks in these two additional environments. Comparison of the two materials in each of the elevated humidity environments is summarized in Table 3. From this comparison involving 9 different properties, the following observations are made.

- At 125F 70\%RH, 1 property (weight) degraded faster for the softwood fiberboard samples than for any of the cane fiberboard samples. One property (radial orientation thermal conductivity) degraded faster for the cane fiberboard sample than for the softwood fiberboard sample. The other properties showed no significant difference.

- At 160F 50\%RH, 3 properties (density, area under stress-strain curve parallel orientation, and axial orientation thermal conductivity) degraded faster for the softwood fiberboard samples than for any of the cane fiberboard samples. Two properties (height and length/width) degraded faster for the cane fiberboard samples than for the softwood fiberboard sample. The other properties showed no significant difference.

- At 185F 30\%RH, 3 properties (weight, height and axial orientation thermal conductivity) degraded faster for the softwood fiberboard samples than for any of the cane fiberboard samples. For an additional 2 properties (length/width, and density) one of the two softwood fiberboard samples degraded faster than any of the cane fiberboard samples.

- At 185F 30\%RH, 2 of the mechanical properties (buckling strength, and area under stressstrain curve parallel orientation) degraded faster for the softwood fiberboard samples than for any of the cane fiberboard samples. However, the weaker cane fiberboard source packages were not aged and tested in this environment. The softwood fiberboard is expected to behave similar to the weaker packages based on comparison to the stronger cane fiberboard packages and the similarity between softwood fiberboard and the weaker cane fiberboard packages in other environments.

- In the above comparisons, softwood fiberboard was identified as degrading faster than cane fiberboard if the softwood fiberboard sample value(s) fell entirely outside the range observed for cane fiberboard. If the softwood fiberboard data fell within the range observed for cane fiberboard (regardless of where it fell within the range) the comparison was identified as showing no significant difference.

- Given the limited duration of aging at $125 \mathrm{~F} 70 \% \mathrm{RH}$ and $160 \mathrm{~F} 50 \% \mathrm{RH}$, these comparisons are tentative. However, the data to date suggest that softwood fiberboard does not experience an increased rate of degradation relative to cane fiberboard in all elevated humidity environments.

In the dry oven environments, the thermal conductivity samples (both orientations) have degraded at a slower rate than the corresponding cane fiberboard samples at 250F, and at approximately the same rate at $215 \mathrm{~F}$ (Figure 7). 
Specific heat capacity, measured at a mean temperature of $125 \mathrm{~F}$, shows little difference between the two materials, although a moderate degree of scatter is observed in the data. Specific heat capacity is measured on softwood samples conditioning at 250F and $185 \mathrm{~F} 30 \% \mathrm{RH}$ only.

Variation has been seen in the properties of cane fiberboard, as illustrated in the comparative data shown in Table 1 (physical properties), Table 2 (thermal conductivity) and Figures 4 and 5 (compression strength). This reflects the inherent variability of this heterogeneous material. One would also expect variability in the properties of softwood fiberboard, although softwood fiberboard is more consistent in its range of fiber size and overall texture. For the current task, all softwood fiberboard samples were obtained from a single assembly, and do not provide any indication of the degree of variation that might exist in other assemblies.

Previous baseline testing [7] provides some indication of variation in softwood fiberboard properties. Baseline softwood fiberboard samples were tested from material laminated by KnightCelotex at their Danville and Marrero plants. The metrics for these baseline samples indicate this material is weaker and absorbed less energy than the baseline samples from the current effort. Since the baseline compression strength of the softwood fiberboard from the current effort is similar to the average from cane fiberboard assemblies, the indication from these data is that softwood fiberboard may be weaker, on average, than cane fiberboard. It is recommended that softwood fiberboard samples from additional assemblies be tested (with and without aging) when they become available.

\section{Conclusions}

Overall, similar aging trends are observed for softwood and cane fiberboard samples, with a few differences. There are modest differences between the two materials in several properties following aging in some of the environments. However, there is no clear overall trend to indicate either material is significantly inferior to the other. The softwood fiberboard data collected to date shows less sample-to-sample variation in physical properties than cane fiberboard, although this test effort includes softwood fiberboard samples from a single package only.

The softwood fiberboard physical property samples conditioning at $185 \mathrm{~F} 30 \% \mathrm{RH}$ generally show degradation rates greater than cane fiberboard samples in this environment. However, this trend has not been seen yet in the other elevated humidity environments that were added to the test matrix during the past year. Continuation of this testing is recommended, particularly for the recently added environments.

The limited source for softwood fiberboard material to date provides little data to understand the range of scatter that might be inherent in this material. Data from additional softwood fiberboard assemblies should be obtained as the material becomes available. 


\section{References}

[1] WSRC-STI-2008-00329, "Review of Data Comparing Softwood Fiberboard and Cane Fiberboard Properties Relevant to 9975 Shipping Packages”, W.L. Daugherty, June 2008.

[2] WSRC-TR-2008-00024, “Task Technical and Quality Assurance Plan for Testing to Support Acceptance into KAMS of Model 9975 Packages with Softwood Fiberboard Overpack (U)”, January 2008.

[3] WSRC-TR-2001-0286, Rev. 2, "SRS Surveillance Program for Storage of Pu Material in KAMS”.

[4] PVP2007-26114, "Properties of Fiberboard Overpack Material in the 9975 Shipping Package following Thermal Aging”, W. L. Daugherty, Proceedings of PVP 2007 Conference, July 2007, ASME.

[5] WSRC-STI-2006-00121, "Degradation of Fiberboard in Model 9975 Package Following Environmental Conditioning - First Interim Report”, W. L. Daugherty and S. P. Harris, May 2007.

[6] SRNL-TR-2010-00388, “Second Status Report: Testing of Aged Softwood Fiberboard Material for the 9975 Shipping Package”, W. L. Daugherty, December 2010.

[7] SRNL-MST-2008-00043, "Properties of Un-Aged Knight-Celotex Softwood Fiberboard for Thermal Modeling”, W. L. Daugherty, February 27, 2008. 
Table 1. Physical property changes in softwood (2 samples) vs cane fiberboard (range of 5 - 8 samples per environment) over the stated aging period. Rates of change for softwood fiberboard are in bold if they fall outside the range observed for cane fiberboard samples.

\begin{tabular}{|c|c|c|c|c|}
\hline & & & Softwood Fiberboard & Cane Fiberboard \\
\hline Property & Environment & $\begin{array}{l}\text { Aging Period } \\
\text { (days) }\end{array}$ & $\begin{array}{l}\text { Rate of Change } \\
(\% / y r)\end{array}$ & $\begin{array}{l}\text { Rate of Change } \\
(\% / y r)\end{array}$ \\
\hline \multirow[t]{6}{*}{ Weight } & 250F, dry & 1036 & $-12.57,-12.47$ & -15.57 to -13.08 \\
\hline & 215F, dry & 1057 & $-3.62,-3.46$ & -3.76 to -3.02 \\
\hline & 185F, dry & 1075 & $-1.35,-1.24$ & -2.04 to -0.88 \\
\hline & $185 \mathrm{~F}, 30 \% \mathrm{RH}$ & 773 & $-6.10,-6.06$ & -5.07 to -3.59 \\
\hline & 160F, 50\%RH & 269 & $-4.58,-4.41$ & -6.54 to -3.94 \\
\hline & 125F, $70 \% \mathrm{RH}$ & 265 & $-1.34,-1.25$ & -0.48 to -0.04 \\
\hline \multirow[t]{6}{*}{ Density } & 250F, dry & 1036 & $-6.75,-6.04$ & -8.97 to -7.33 \\
\hline & 215F, dry & 1057 & $-0.92, \quad-0.86$ & -1.94 to +0.05 \\
\hline & 185F, dry & 1075 & $-0.09,+0.02$ & -0.88 to +0.51 \\
\hline & 185F, 30\%RH & 773 & $-2.91,-2.64$ & -2.79 to -1.30 \\
\hline & 160F, 50\%RH & 269 & $-3.21,-3.14$ & -1.99 to -0.31 \\
\hline & $125 \mathrm{~F}, 70 \% \mathrm{RH}$ & 265 & $-1.57,-1.34$ & -2.02 to -0.29 \\
\hline \multirow[t]{6}{*}{ Height } & 250F, dry & 1036 & $-5.29,-4.92$ & -6.48 to -3.91 \\
\hline & 215F, dry & 1057 & $\mathbf{- 1 . 6 6 ,}-1.55$ & -1.56 to -1.04 \\
\hline & 185F, dry & 1075 & $\mathbf{- 0 . 8 0}, \quad-0.63$ & -0.77 to -0.35 \\
\hline & 185F, 30\%RH & 773 & $-2.10, \quad-2.07$ & -1.93 to -1.20 \\
\hline & 160F, 50\%RH & 269 & $-1.59,-1.29$ & -3.05 to -2.07 \\
\hline & $125 \mathrm{~F}, 70 \% \mathrm{RH}$ & 265 & $-0.15,-0.02$ & -0.34 to +1.21 \\
\hline \multirow{6}{*}{$\begin{array}{l}\text { Length, } \\
\text { Width }\end{array}$} & 250F, dry & 1036 & -1.50 to $\mathbf{- 0 . 8 2}$ & -3.78 to -0.91 \\
\hline & 215F, dry & 1057 & -0.56 to -0.44 & -1.35 to -0.29 \\
\hline & 185F, dry & 1075 & -0.27 to -0.23 & -0.52 to -0.03 \\
\hline & 185F, 30\%RH & 773 & $\mathbf{- 0 . 9 4}$ to -0.60 & -0.61 to -0.20 \\
\hline & $160 \mathrm{~F}, 50 \% \mathrm{RH}$ & 269 & -0.10 to +0.13 & -1.24 to -0.52 \\
\hline & $125 \mathrm{~F}, 70 \% \mathrm{RH}$ & 265 & -0.27 to +0.66 & -0.57 to +0.68 \\
\hline
\end{tabular}


Table 2. Thermal conductivity changes in softwood (1 sample per environment / orientation) vs cane fiberboard (range of 1 - 4 samples per environment / orientation) over the stated aging period. Rates of change for softwood fiberboard are in bold if they fall outside the range observed for cane fiberboard samples.

\begin{tabular}{|l|l|l||l||l|}
\hline \multirow{2}{*}{ Orientation } & Environment & $\begin{array}{l}\text { Aging Period } \\
\text { (weeks) }\end{array}$ & $\begin{array}{l}\text { Roftwood Fiberboard } \\
\text { (\%/yr) }\end{array}$ & Cane Fiberboard \\
\hline \hline \multirow{5}{*}{ Axial } & 250F, dry & 108 & $-\mathbf{5 . 6 3}$ & -7.99 to -7.41 \\
\cline { 2 - 5 } & $215 \mathrm{~F}$, dry & 32 & -2.18 & -2.46 to -1.93 \\
\cline { 2 - 5 } & $185 \mathrm{~F}, 30 \% \mathrm{RH}$ & 32 & $-\mathbf{3 . 6 6}$ & -2.76 to -2.33 \\
\cline { 2 - 5 } & $160 \mathrm{~F}, 50 \% \mathrm{RH}$ & 153 & $-\mathbf{4 . 0 1}$ & -3.59 to -0.45 \\
\cline { 2 - 5 } & $125 \mathrm{~F}, 70 \% \mathrm{RH}$ & 153 & +0.15 & -0.11 to +2.48 \\
\hline \multirow{3}{*}{ Radial } & $250 \mathrm{~F}$, dry & 108 & $-\mathbf{9 . 1 8}$ & -12.56 to -10.06 \\
\cline { 2 - 5 } & $215 \mathrm{~F}$, dry & 32 & -2.56 & -2.71 to -1.82 \\
\cline { 2 - 5 } & $185 \mathrm{~F}, 30 \% \mathrm{RH}$ & 32 & -2.92 & -3.56 to -1.96 \\
\cline { 2 - 5 } & $160 \mathrm{~F}, 50 \% \mathrm{RH}$ & 153 & 0.00 & -1.77 to +2.97 \\
\cline { 2 - 5 } & $125 \mathrm{~F}, 70 \% \mathrm{RH}$ & 153 & +2.08 & +2.48 \\
\hline
\end{tabular}


Table 3. Comparison of softwood and cane fiberboard behavior in elevated humidity environments

\begin{tabular}{|c|c|c|c|}
\hline & 125F 70\%RH & 160F 50\%RH & 185F 30\%RH \\
\hline \multicolumn{4}{|l|}{ Physical Properties } \\
\hline Weight & $\begin{array}{l}\text { Softwood samples } \\
\text { degrading faster than } \\
\text { all cane samples }\end{array}$ & $\begin{array}{l}\text { No significant } \\
\text { difference }\end{array}$ & $\begin{array}{l}\text { Softwood samples degrading } \\
\text { faster than all cane samples }\end{array}$ \\
\hline Height & $\begin{array}{l}\text { No significant } \\
\text { difference }\end{array}$ & $\begin{array}{l}\text { Cane samples } \\
\text { degrading faster than } \\
\text { either softwood } \\
\text { sample }\end{array}$ & $\begin{array}{l}\text { Softwood samples degrading } \\
\text { faster than all cane samples }\end{array}$ \\
\hline Length. Width & $\begin{array}{l}\text { No significant } \\
\text { difference }\end{array}$ & $\begin{array}{l}\text { Cane samples } \\
\text { degrading faster than } \\
\text { either softwood } \\
\text { sample }\end{array}$ & $\begin{array}{l}1 \text { of } 2 \text { softwood samples } \\
\text { degrading faster than all cane } \\
\text { samples }\end{array}$ \\
\hline Density & $\begin{array}{l}\text { No significant } \\
\text { difference }\end{array}$ & $\begin{array}{l}\text { Softwood samples } \\
\text { degrading faster than } \\
\text { all cane samples } \\
\end{array}$ & $\begin{array}{l}1 \text { of } 2 \text { softwood samples } \\
\text { degrading faster than all cane } \\
\text { samples }\end{array}$ \\
\hline \multicolumn{4}{|c|}{ Compression Strength } \\
\hline Buckling Strength & $\begin{array}{l}\text { No significant } \\
\text { difference }\end{array}$ & $\begin{array}{l}\text { No significant } \\
\text { difference }\end{array}$ & $\begin{array}{l}\text { Softwood samples degrading } \\
\text { faster than cane samples (but } \\
\text { weakest cane package not } \\
\text { aged/tested in this } \\
\text { environment) }\end{array}$ \\
\hline $\begin{array}{r}\text { Area under Stress- } \\
\text { Strain Curve, } \\
\text { parallel }\end{array}$ & $\begin{array}{l}\text { No significant } \\
\text { difference }\end{array}$ & $\begin{array}{l}\text { Softwood samples } \\
\text { degrading faster than } \\
\text { all cane samples }\end{array}$ & $\begin{array}{l}\text { Softwood samples degrading } \\
\text { faster than cane samples (but } \\
\text { weakest cane package not } \\
\text { aged/tested in this } \\
\text { environment) }\end{array}$ \\
\hline $\begin{array}{r}\text { Area under Stress- } \\
\text { Strain Curve, } \\
\text { perpendicular }\end{array}$ & $\begin{array}{l}\text { No significant } \\
\text { difference }\end{array}$ & $\begin{array}{l}\text { No significant } \\
\text { difference }\end{array}$ & No significant difference \\
\hline \multicolumn{4}{|l|}{ Thermal Conductivity } \\
\hline Axial & $\begin{array}{l}\text { No significant } \\
\text { difference }\end{array}$ & $\begin{array}{l}\text { Softwood sample } \\
\text { degrading faster than } \\
\text { all cane samples } \\
\end{array}$ & $\begin{array}{l}\text { Softwood sample degrading } \\
\text { faster than all cane samples }\end{array}$ \\
\hline Radial & $\begin{array}{l}\text { Cane sample } \\
\text { degrading faster than } \\
\text { softwood sample }\end{array}$ & $\begin{array}{l}\text { No significant } \\
\text { difference }\end{array}$ & No significant difference \\
\hline
\end{tabular}



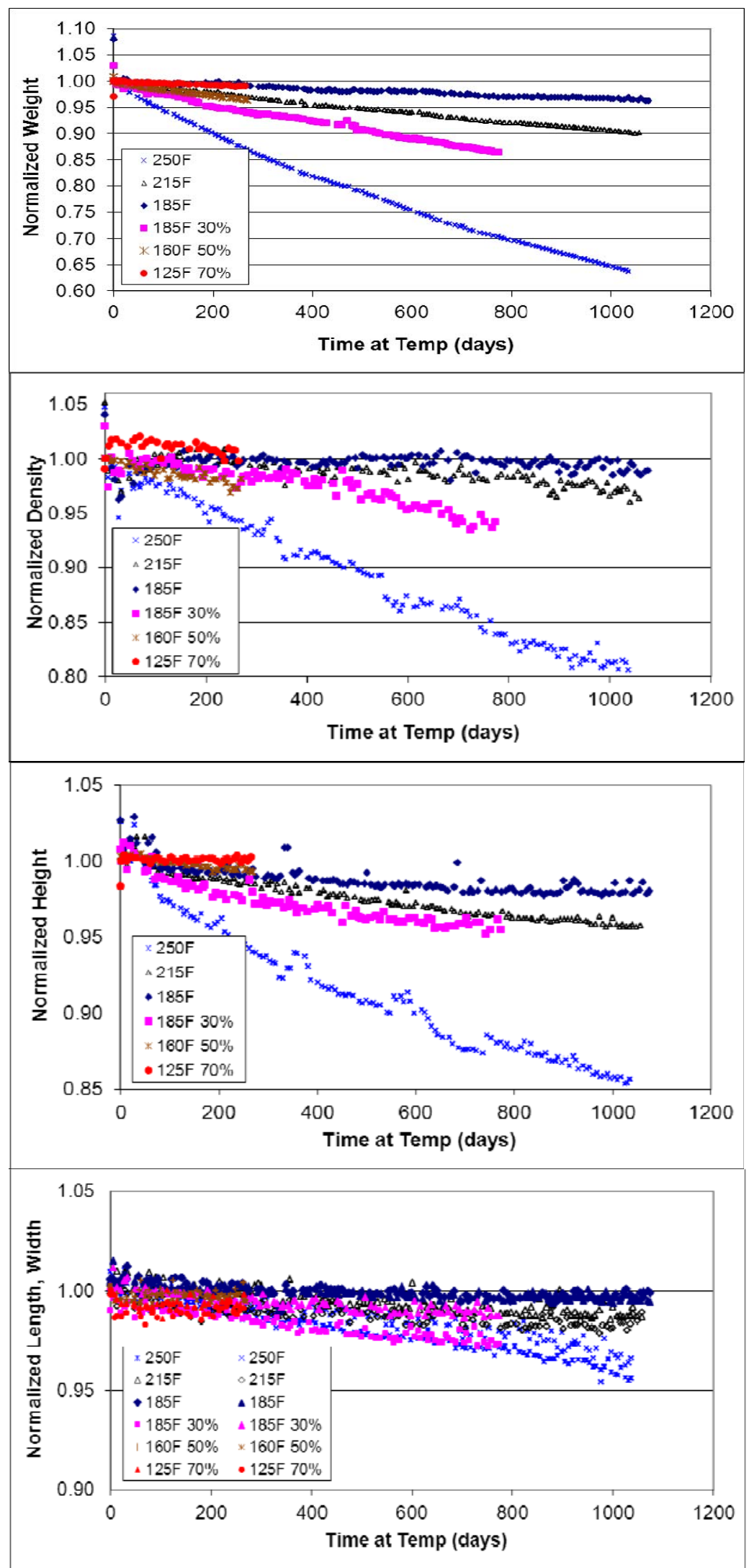

Figure 1. Normalized physical data for softwood fiberboard mass loss samples.

(a) Weight change

(b) Density change

(d) Length / width change 

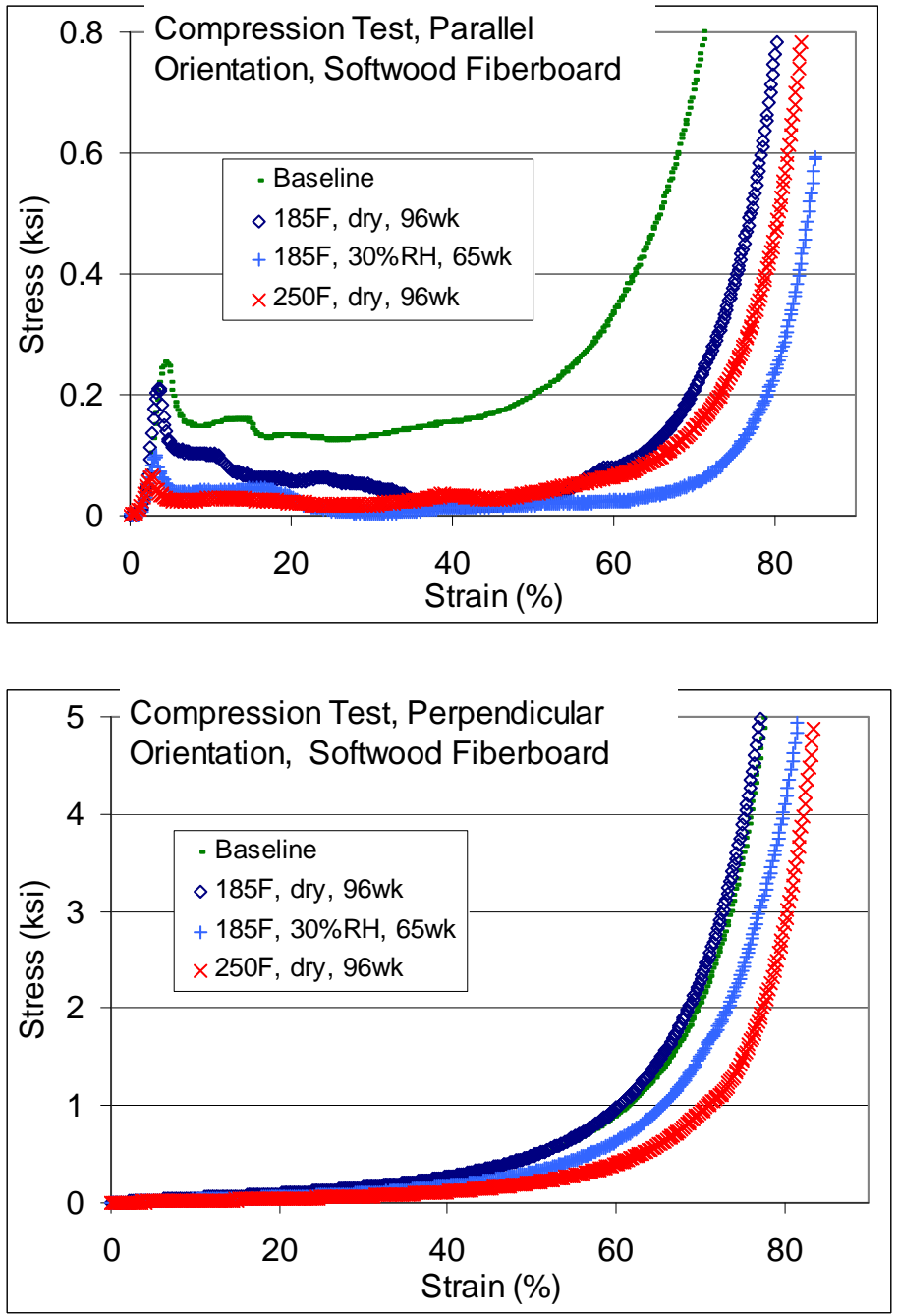

Figure 2. Typical compression stress-strain curves for softwood fiberboard samples, parallel orientation

Figure 3. Typical compression stress-strain curves for softwood fiberboard samples, perpendicular orientation 

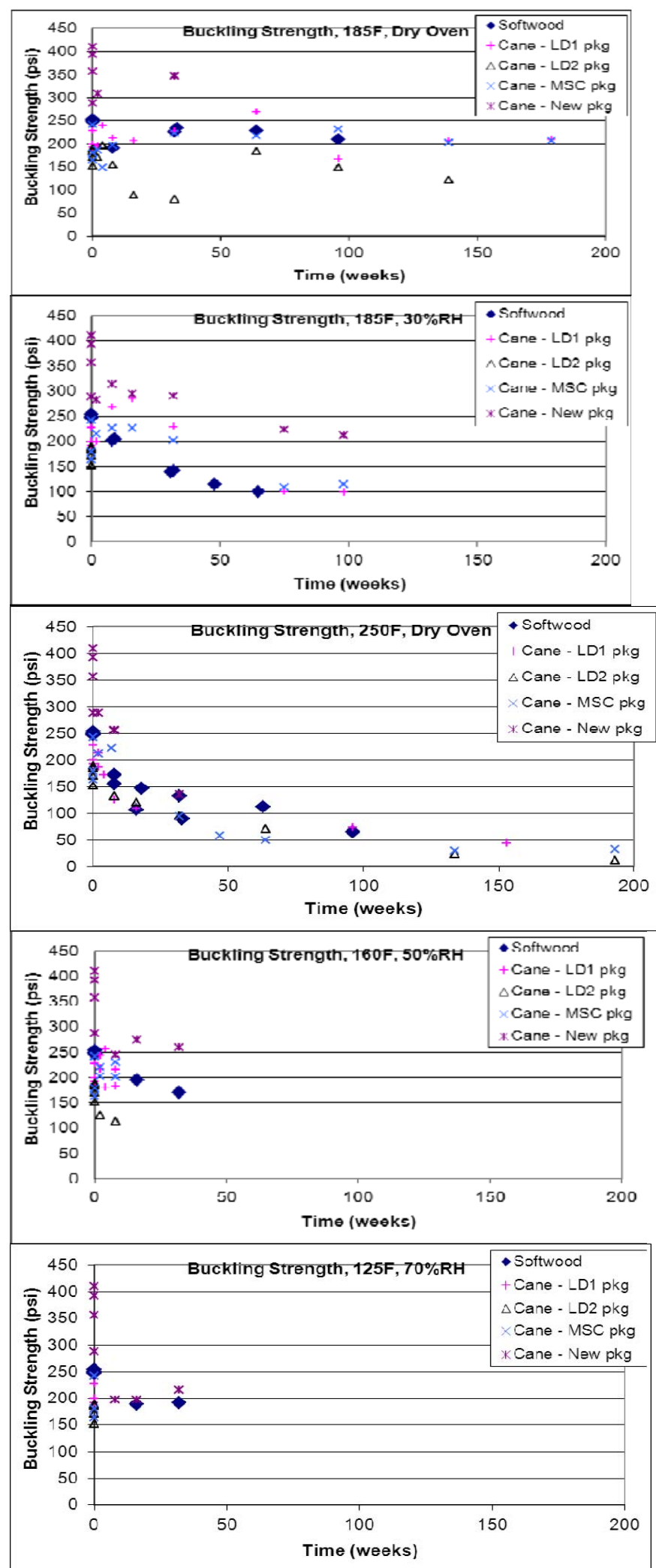
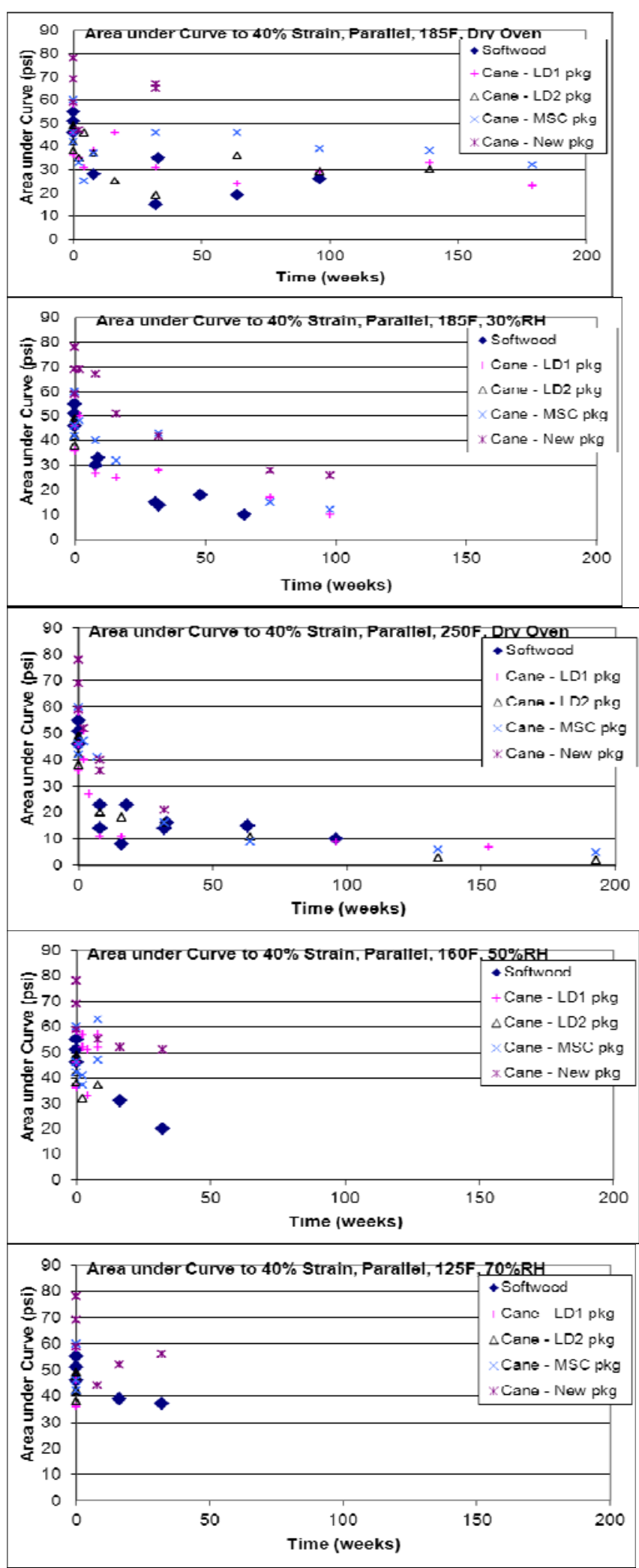

Figure 4. Compression test metrics (buckling strength, area under curve to 40\% strain) for parallel orientation samples. 

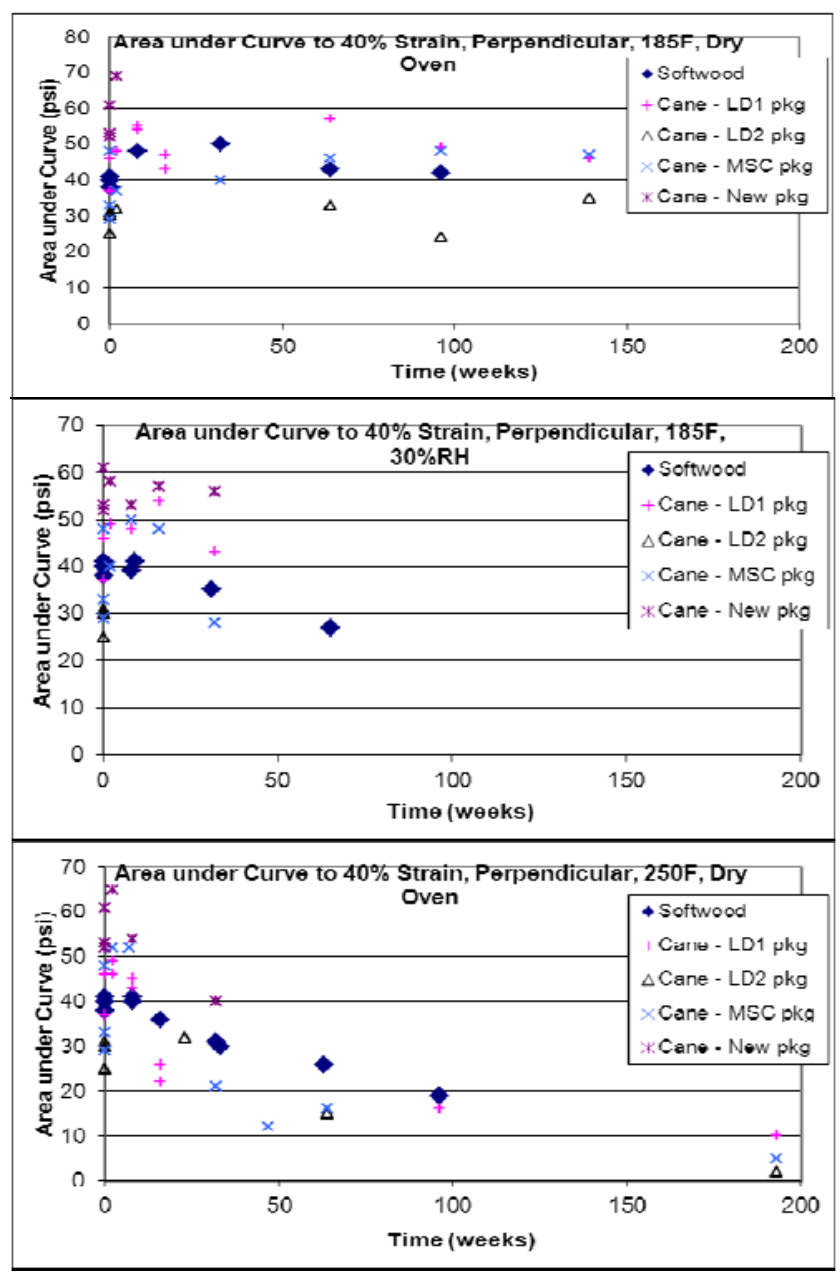

Figure 5. Compression test metric (area under curve to $40 \%$ strain) for perpendicular orientation samples.
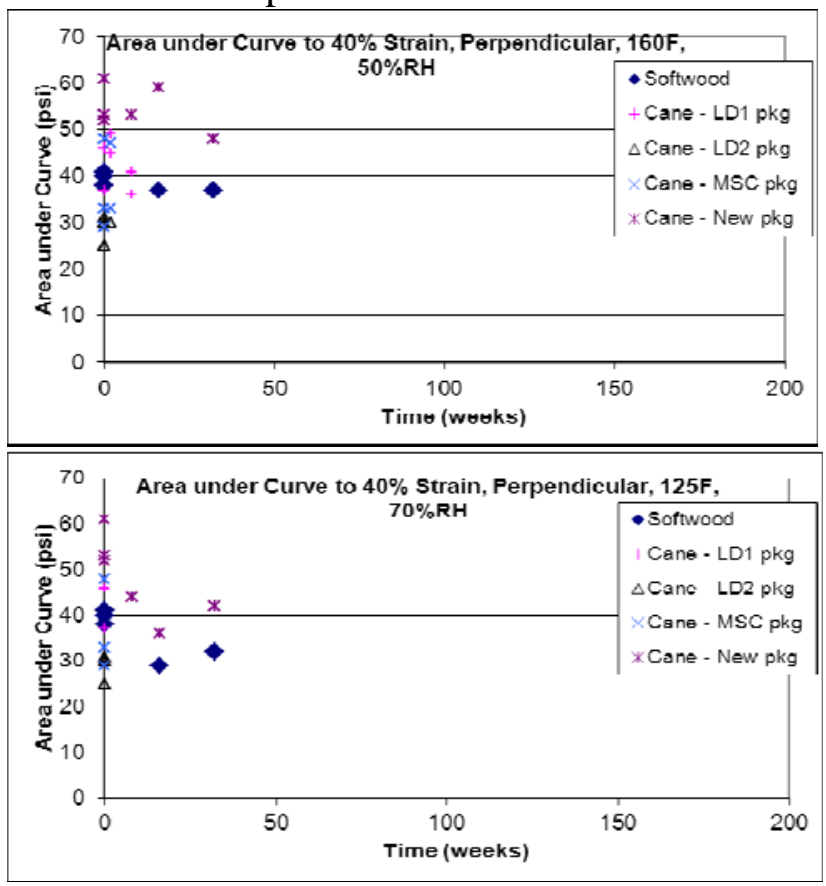


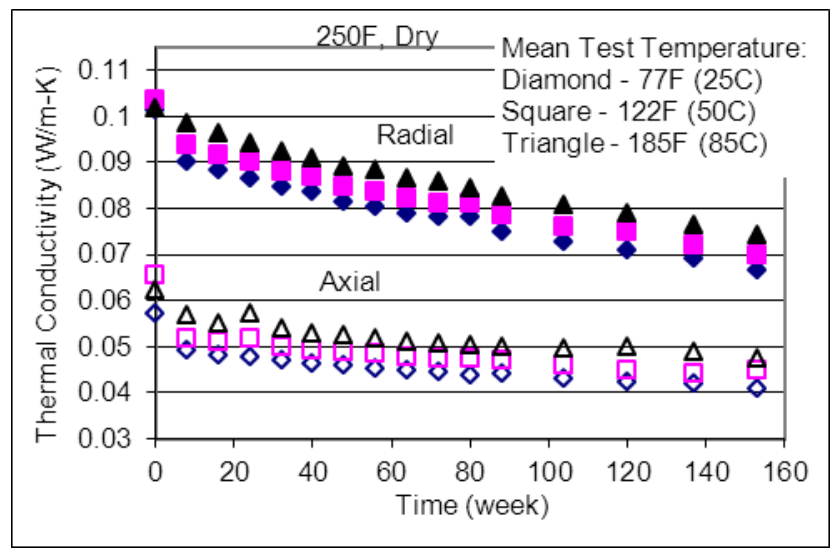

(a) 250F oven

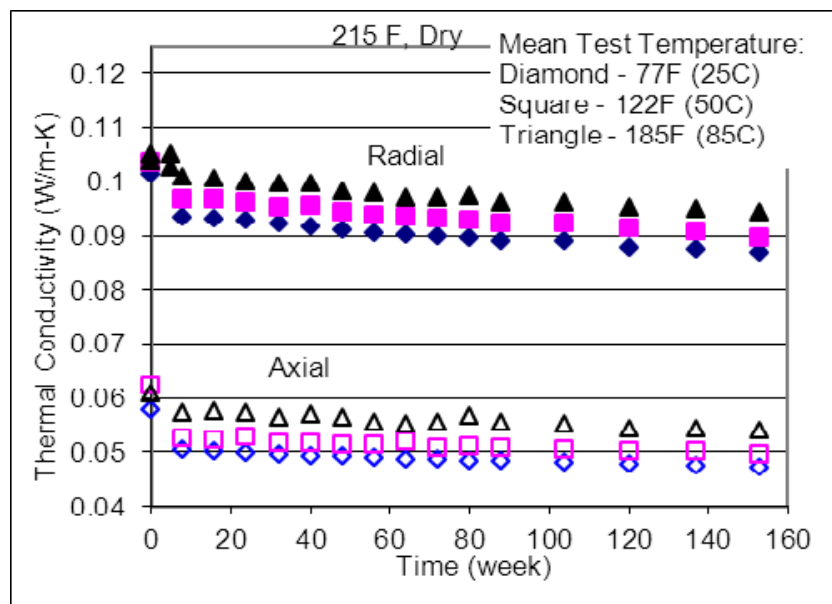

(b) $215 \mathrm{~F}$ oven

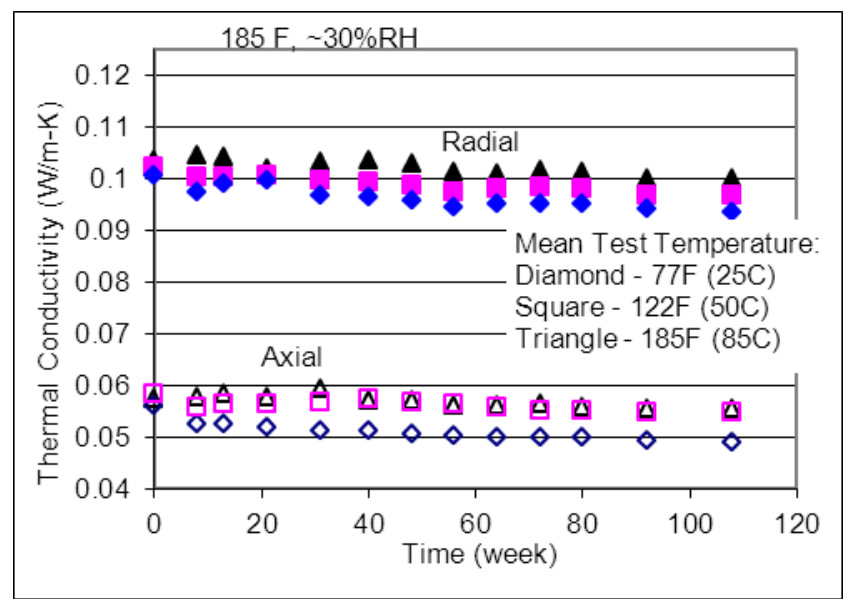

(c) $185 \mathrm{~F} 30 \% \mathrm{RH}$ chamber
Figure 6. Thermal conductivity data for softwood fiberboard samples conditioned in the indicated environments

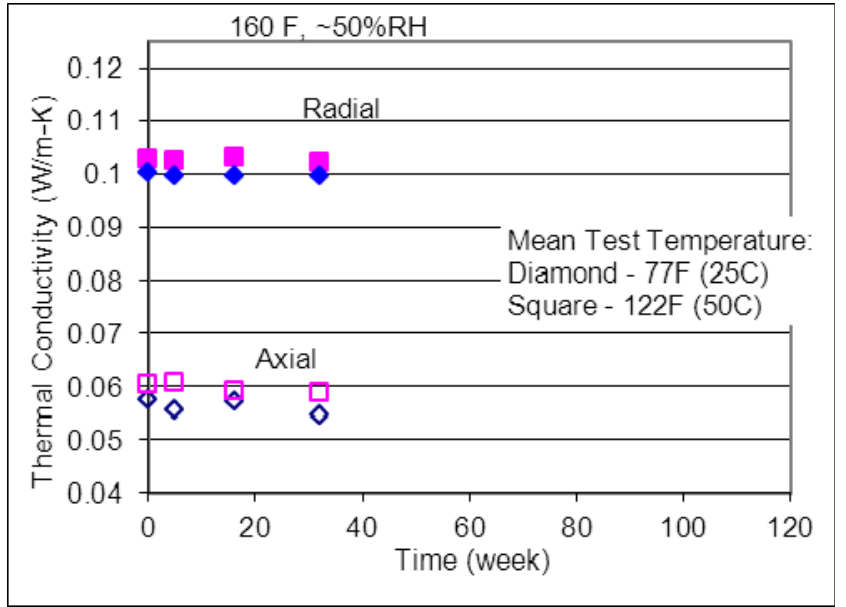

(d) $160 \mathrm{~F} 50 \% \mathrm{RH}$ chamber

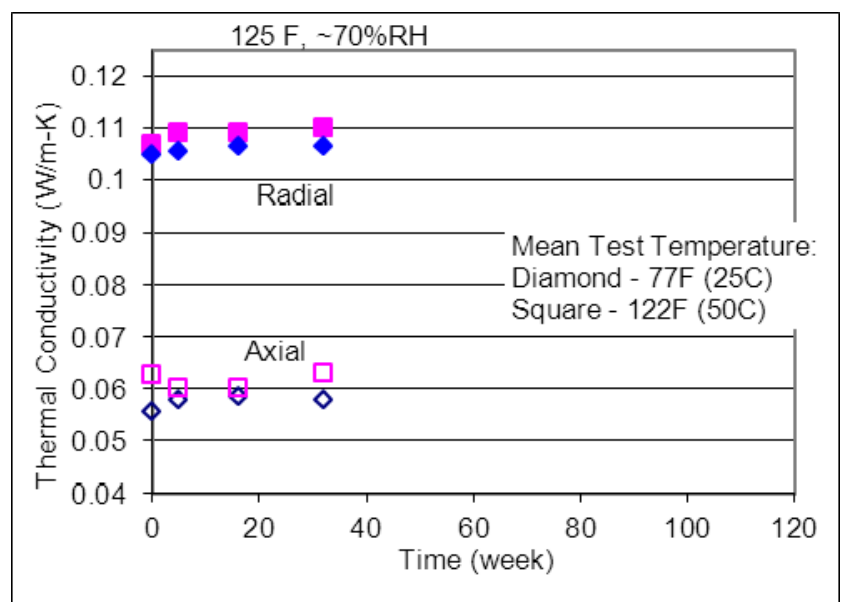

(e) $125 \mathrm{~F} 70 \% \mathrm{RH}$ chamber 


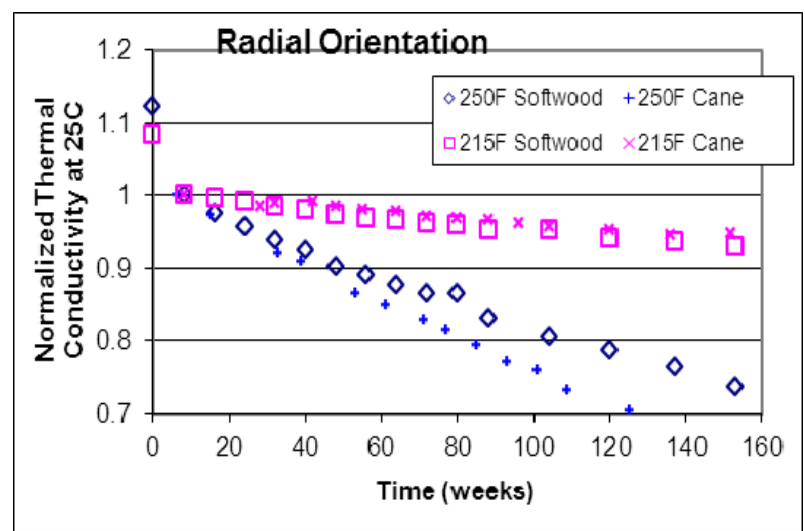

(a) radial orientation, dry oven environments

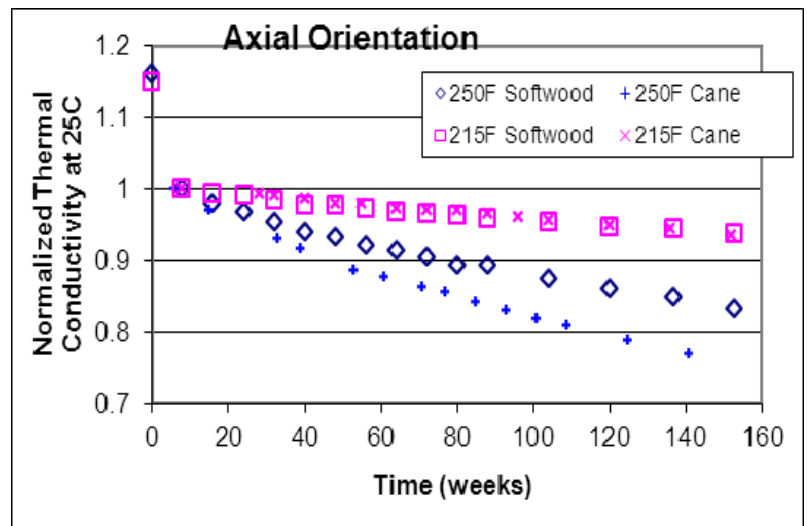

(c) axial orientation, dry oven environments

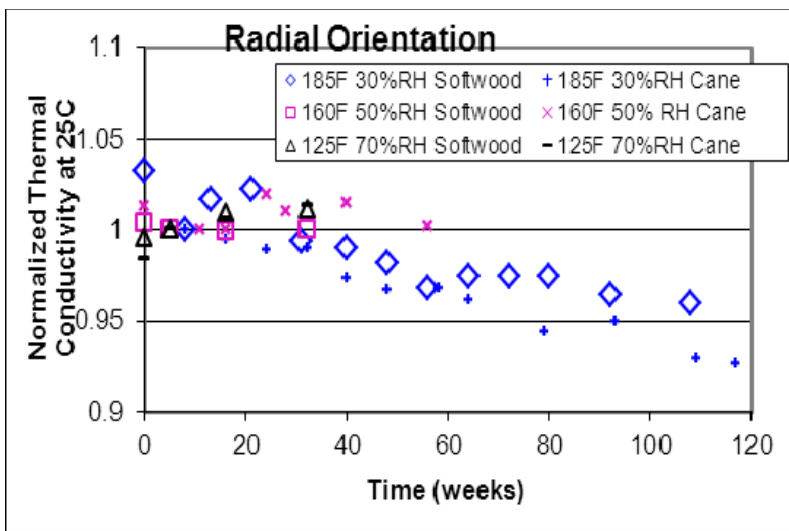

(b) radial orientation, humid environments

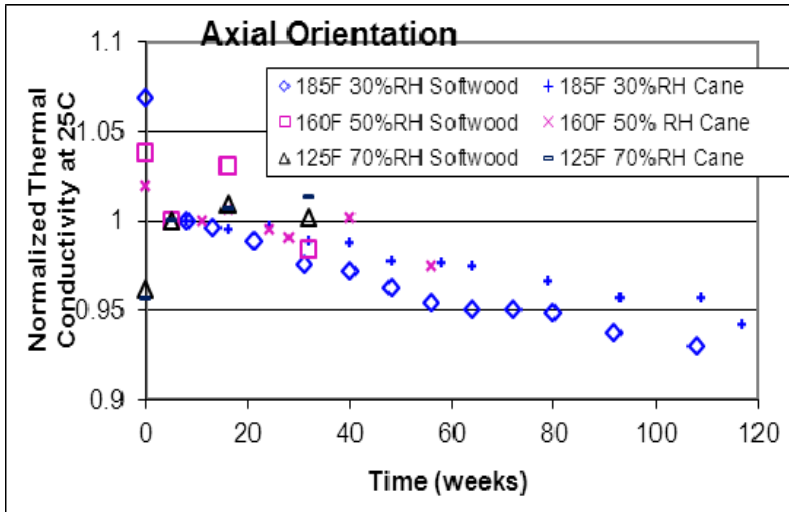

(d) axial orientation, humid environments

Figure 7. Normalized thermal conductivity data for softwood fiberboard compared to typical data for cane fiberboard. A more complete comparison of softwood and cane fiberboard thermal conductivity degradation rates is provided in Table 2.

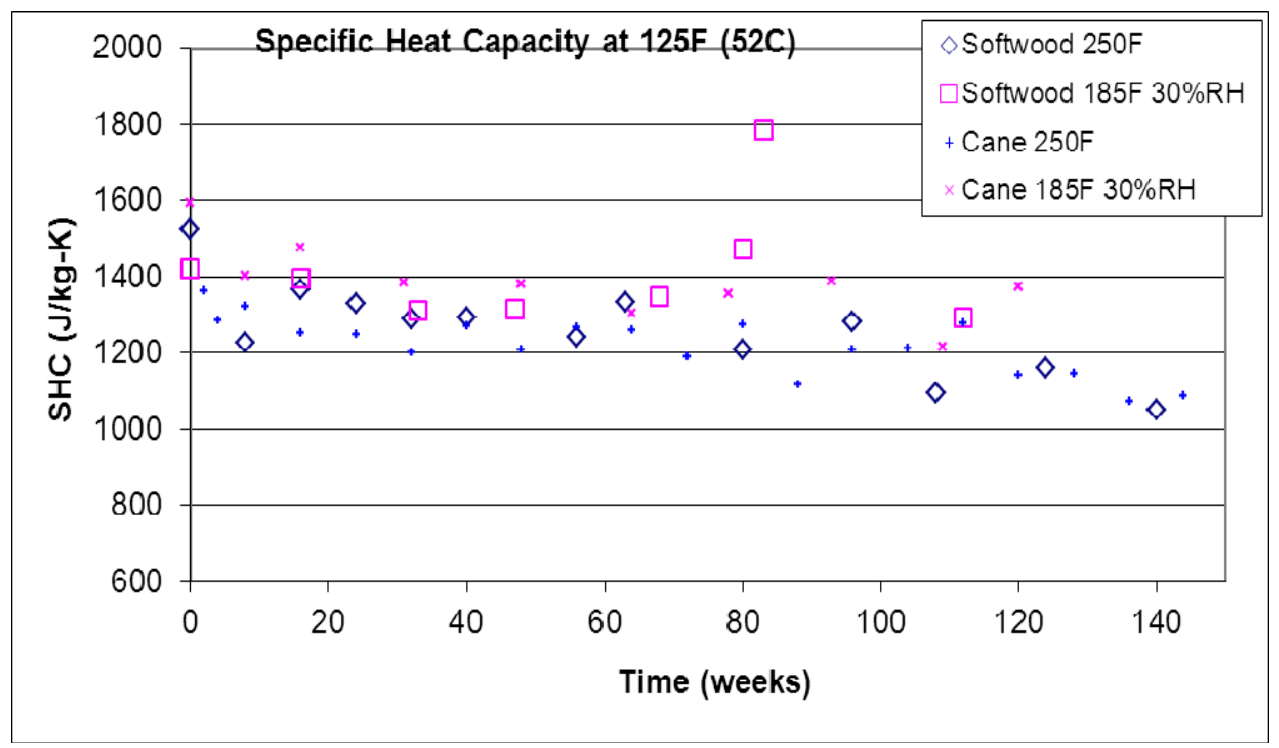

Figure 8. Specific heat capacity data for softwood fiberboard at a mean temperature of 52C, compared with cane fiberboard 
CC: J. S. Bellamy, 730-A

G. T. Chandler, 773-A

J. A. D'Amelio, 705-K

W. L. Daugherty, 773-A

K. A. Dunn, 773-41A

B. A. Eberhard, 105-K

T. J. Grim, 105-K

E. R. Hackney, 705-K

D. R. Leduc, 730-A

J. W. McClard, 705-K

J. W. McEvoy, 707-C

D. L. Melvin, 705-K

T. M. Monahon, 705-K

J. L. Murphy, 730-A

W. W. Osborne, 705-K

A. C. Reedy, 705-K

T. E. Skidmore, 730-A

A.J. Stapf, 717-K

Document Control 